\title{
E. M. Forster's A Passage to India: A Tragedy of Cultural Conflicts and Distorted Interracial Relationships
}

\author{
Rashed Daghamin \\ University of Hail, Saudi Arabia
}

\begin{abstract}
E.M. Forster's A Passage to India, hereafter (API), offers us an opportunity to realize the mentality of the white imperialist and the grotesque picture of the colonizer-colonized relationship; this picture implies multiple facets of racial vituperations, brutality, and prejudice perpetrated on Indians in the colonial period. In the novel, Forster explores the colonizers' racist attitudes, and he brings out the racial and interracial conflicts as well as the cultural and ethnic traumas between the colonizer and the colonized. This study is primarily concerned with exploring the cultural clashes and the problematic, deformed interracial relationships, established between the Indians and the Anglo-Indians in a colonial context. The analytical approach and the Postcolonial Theory will be adopted throughout the paper as a framework. A postcolonial reading of the novel debunks the colonizer's racist ideology and reveals various motifs of partitions, fences, interracial conflicts and gulfs. The article reveals that the different racial, cultural, and social backgrounds of the English and Indian communities create bitter differences and significant gaps that cannot be bridged. The study concludes that the ramifications of the interracial clashes and racial intolerance have a vehement impact on both the colonized and the colonizer alike; however, mutual and interracial love, respect, and understanding are robust solutions that can relatively open the ideological closure of racism, lessen the racial tensions and thus bring people of different racial backgrounds together.
\end{abstract}

Index Terms - culture, race, conflict, India, English, Forester, relations

\section{A PASSAGE To INDIA IN LIGHT OF COLONIALISM AND THE POSTCOLONIAL THEORY}

Colonialism is a system of hegemony, leverage, supremacy, deliberate subordination and subjugation that the Occident (white imperialists, European colonizers) tried to inflict upon the Orient (the other, the colonized). Nonetheless, colonialism is not restricted to military force or physical coercion only; in fact it has many facets including cultural, psychological, social and economic dimensions. Through the process of colonization, the colonizer adamantly seeks to replace the beliefs, customs, traditions and cultural values of the indigenous natives (the colonized) with his own beliefs, culture and practices. Thus, the colonized view themselves and their culture as powerless, subordinate and inferior to the colonizers. On the other hand, the white imperialists consider themselves and their history and culture as superior. As a result, the so-called "the other" seeks to mimic and imitate his master's culture, language and lifestyle. In light of this, The 'Occident' is viewed as superior, rational, developed, and powerful; however, the 'Orient' or the East is seen as inferior, irrational, weak and uncivilized. In view of this, the colonizer's culture, beliefs, values, and practices are referred to as a criterion to which the oppressed should adhere.

The study of the relationship between the colonizer and the colonized, between the master and the slave, establishes the core of what so- called Postcolonialism. The literature of this era serves as a voice of the marginalized, the colonized, and the oppressed. Postcolonialism sheds light on the cultures and societies of the colonized and subjugated nations, which are consciously and subconsciously influenced by the colonial process. According to Ashcroft et al., "Post-colonialism deals with the effects of colonization on cultures and societies... from the late 1970s the term has been used by literary critics to discuss the various cultural effects of colonization" (1995, p. 168). Postcolonialism seeks to critically examine and investigate what happens when two different cultures and races clash; the colonizer tries to impose his culture, dominance, hegemony and supremacy over the colonized, who gradually start to accept and adapt to the colonizer's culture, language and lifestyle.

The Postcolonial theory moves beyond the boundaries of literary studies to examine and investigate the social, political, economic, and cultural relations and concerns of both the colonized and the colonizer; the other and the powerful, the inferior and the superior. Homi K. Bhabha in his essay entitled, "The postcolonial and the postmodern: the question of Agency", states that, "postcolonial perspectives emerge from the colonial testimony of third world countries and the discourses of minorities within the geopolitical division of East and West, North and South" (1994, p.171). Hence, it can be said that Postcolonial theory provides a clear understanding of how relations between the superior and the inferior are established and manifested in literature.

Postcolonialism refers to the depiction of race, ethnicity, culture and human identity and interracial relations in the modern era; after many colonized countries in Asia, Africa, and the Caribbean gained their independence from Western 
colonizing forces, such as England and France. The era of Postcolonialism is presented in literature with recurring notions and motifs, such as hybridity, identity, otherness, mimicry, language, ambivalence, superiority vs. inferiority, and racism. The colonial encounter between the Occident and the Orient has led to political, historical and cultural consequences, which highlight a western superiority over the locals, who are perceived to be downtrodden, inferior, barbaric, underdeveloped and uncivilized. In an attempt to control and rule over the orients, European colonizers have often set to suppress their culture and values, distort their history, tradition and even language. However, suppressed natives tried to reject such hegemony and resist the inhuman acts of subordination and subjugation so as to save their culture, history, customs and language from loss and disintegration. Postcolonialism can be defined as a literary movement that throws light on the literature written in currently or formerly colonized countries (third world countries), or literature written in imperialist colonizing countries (European and Western countries) which deals with colonization. Postcolonial writings attempt to reclaim, recover and celebrate the cultures, traditions, beliefs, languages, and history of the colonized. Postcolonial literature seeks to resist and subvert the depiction of the colonized as slaves, uncivilized, savage, inferior and marginal by the colonizer. Postcolonial literature, therefore, attempts to celebrate and underscore the identity of the colonized and reclaim their history, cultural values, beliefs and practices.

In view of the above, it can be argued that E.M. Forster's API is a postcolonial and anti-imperialistic novel, which reflects a racial antagonism and a colonial attitude of supremacy; therefore the novel debunks the white imperialists' ideology and it mocks the myth of the "White Man's Burden". Indians, being the other, marginalized and suppressed community are depicted with some racial and typical stereotypes that the British colonizers associated with them. Hence, $A P I$ is a postcolonial literary text because it crystallizes the concept of untouchable, marginalization, subjugation, racial tensions, and racial intolerance, between two unequaled forces; the Orient and the Occident. According to Clare Brandabur, the novel "attempt[s] to deal with colonialism (or post-colonialism or neo-colonialism) with respect to the destructive impact on personal relationships caused by the racist assumptions and psycho-pathology inherent in colonial imperialism" (1993, p.19). This paper is an attempt to bring out interracial conflicts and ethnic traumas between two dissimilar races (Indian subalterns and the British colonizers).

\section{INTRODUCTION}

API was written in 1913 and published in 1924 by E.M. Forster. According to J. B. Priestley, "A Passage to India, which adds racial relationships to the intricate pattern, is even more elaborate: a novel that requires several readings to be appreciated to the full, undoubtedly Forster's masterpiece" (1962, p. 355). The writer "represents the finest and most human in the liberal spirit, began in "A Passage to India" the tradition of using Indian life as an image of personal experiences' (Ford, 1983, p. 319). The novel is inspired primarily from the author's experience in India as a short-term resident and from his interactions with Indians and with the British servants, called Anglo-Indians; "a narrow-minded caste of chauvinistic snobs" (Pirnuta, 2007, p. 380). Although API is highly symbolic and mystical in its themes, it aims to be a truthful documentation of the racist attitudes of British officials in India, chiefly in Chandapore, a city along the Ganges River, and remarkable only for the nearby Marbar caves. The author reveals his personal experiences and interactions with the locals during his double visits to colonial India.

E.M. Forster was different from the authors of his time, whereas their works were going out of the literary fashion, Forster's was coming into it, Priestly argues that:

He rejected from the first any idea of being a solid chronicler of a society, of filling with realistic detail a broad of canvas, of making his narrative acceptable and convincing by accumulating representative characters and events. He works in brilliant flashes, sudden revelations of character, glimpses of heights and depths, action that is not realistic and typical but symbolic. (1962, p. 355)

Rajni Devi points out that Forster demonstrates how recurrent misunderstandings become hardened into cultural and racial stereotypes and are frequently used to justify the futility of efforts to bridge the cultural gaps between the two dissimilar groups $(2017$, p. 223). Therefore, it can be claimed that such interracial misunderstandings and cultural conflicts have resulted from the different cultural, ethnic, religious and social backgrounds of the rulers and the ruled; as a result, these variations have caused interracial tensions and conflicts between the Indian and English characters. Owing to these differences, both communities fail to enjoy an eternal union and genuine friendship, and they are finally split into two parts on the ground of their racial beliefs. For the duration of Dr. Aziz's arrest, Mr. Turton informs Cyril Fielding that, "I have had twenty-five years' experience of this country... I have never known anything but disaster result when English people and Indians attempt to be intimate socially" (API, p. 86). Adela Quested displays her ignorance of Indian traditions when she asks Dr. Aziz how many wives he has. Moreover, the Turton sets up a party to bridge the gulf between the East and West; however, this event emphasizes the ongoing tension between the two different cultures. Mrs. Moore also observes that India is filled of "mystery and muddle" that westerners cannot fathom (API, p. 224).

The interracial associations between the Indians and the British and their unceasingly growing conflict brought about cultural and racial misunderstanding and religious variations are clearly portrayed in the main parts of the novelMosque, Caves, and Temple (Devi, 2017, p. 223). When Aziz accompanies Adela Quested to the Caves, Quested accuses him with attempting to rape and assault her. Aziz's trial therefore brings all the racial, cultural and ethnic tensions, bigotries and partialities between the ruled and the rulers. 
Mason claims that the novel brings the voices of Dr. Aziz and the other Indian characters to the forefront (Mason, 2016, p.31). The first character whom we are introduced to in the novel is Dr. Aziz, a Muslim Indian doctor, followed by his close Indian friends Hamidullah and Mahmoud Ali. It is in this part of the book that these characters present the fundamental question of the novel: whether or not it is possible for an Indian citizen to befriend an English native. Each part of the novel adds a new perspective on this idea; the "Mosque," part establishes the friendships between Aziz and the English, the second part, "Caves," breaks these relationships, and the final part, "Temple," implies a glimmer of hope and union once India is decolonized (Lan, 2013, p. 493). However, although the main focus of the novel is the friendship and the unhealthy relationship between Dr. Aziz and Fielding, the English female characters in the book aggravate the tensions; they initiate, muddle and complicate all parts of the book (Mason, 2016, p. 31).

$A P I$ is therefore an exploration of the distorted interracial relationships between the East and West. E M. Forster's novel presents a clinical depiction of the two different communities. Thus, Forster's masterpiece thoroughly explores and examines the fences of interracial friendship and relationships in a colonial context. APA is a living typical example of how two different cultures when enforced to intermingle, misunderstandings and conflicts surface. As a result, it can be said that the implications and repercussions of such conflicts and misunderstandings are detrimental and poignant on all levels: individual, racial and cultural. The book hence casts light on the disillusionments of arrogant and shallowminded people, who fail to deal with one another on equal basis and subsequently eradicate racial intolerance and prejudice and establish healthy friendships.

At the end of the book, Dr. Aziz informs Cyril Fielding that, 'It is useless discussing Hindus with me. Living with them teaches me no more. When I think I annoy them, I do not. When I think I don't annoy them, I do' (API, p.315). In light of this, the writer proves how such frequent misunderstandings and cultural conflicts become coarsened into cultural stereotypes, and how they are frequently used to rationalize the absurdities, pointlessness and emptiness of efforts and attempts to bridge the racial and cultural gulfs. When Dr. Aziz gives his collar stud to Fielding in a gushing act of love, respect and friendship, Rony Heaslop, later on misunderstands Aziz's missing stud as an oversight and takes it as an example to enforce his beliefs about Indian stereotypes (Pirnuta, 2007, p. 381).

It is believed that spirituality and faith have historically influenced the Indian community on social, cultural, economic and political levels. Therefore, it can be said that Indians are religious-oriented people. In India, spirituality and mysticism are major forces in the way Indian citizens lead their lives, especially if they practice Hinduism; in fact the racial conflict between Christianity and Hinduism in the novel equals the interracial clash between the imperialists and the Indians. Hinduism in the novel is represented by professor Godbole, and Christianity is best exemplified in Mrs. Moore. She comes to the British Raj with great expectations; she socializes with the locals with an open mind, and understanding and devout Christian heart; however, she quits India sullen, peevish and disillusioned as her dreams to discover real India fall apart. On the other hand, Forster does not see anything captivating and surprising in India except some tropical places, this hints to the racial anarchy and rising tension between the two different races. These views of the writer are clearly stated in the first chapter of the novel, he says that:

Except for the Marabar caves- and they are twenty miles off- the city of Chandrapore presents nothing extraordinary. Edged rather than washed by the river Ganges, it trails for a couple of miles along the bank, scarcely distinguishable from the rubbish it deposits so freely. There are no bathing-steps on the river front, as Ganges happens not to be holy here; indeed there is no river front, and bazaars shut out the wide and shifting panorama of the stream, the streets are mean, the temple ineffective. (API, p. 1)

In spite of Forster's biting satire and scathing criticism of the English colonizers' condescending behaviors towards the locals, he does not seem to openly and boldly question the right of the English man to colonize India. Instead, Forster suggests that the English rulers would be served by becoming kinder, more understanding and more sympathetic with the inhabitants. Apparently, Forster does not offer practical and pragmatic solutions to the problematic interracial conflict in colonial India.

\section{ANALYSIS AND DISCUSSION}

The novel is rich with multifarious differences of racial vituperation and cultural misunderstanding. Thus, cultural understandings and interracial misconceptions and barriers are key themes that underline whole the novel. According to Priestly: "A Passage to India, which adds racial relationships (though these are not its subject) to the intricate pattern, is even more elaborate: a novel that requires several readings to be appreciated to the full, undoubtedly Forster's masterpiece" (1962, p. 355). The book delineates and excoriates racial and interracial intolerance, bigotry, tension, and cultural conflicts between two different races dissimilar on the cultural and intellectual levels. The novel describes racial and culture gulfs which swerve the English expatriates and the locals apart. Clashes occur when the English colonialists and the indigenous natives (West and East) "do not see eye to eye" (Ashcroft, 1959, p. 19). The frequent misunderstandings highlighted in the book include Aziz's collar stud; Bhattacharya's invitation; the organization of the Bridge Party; the choice of the woman Fielding espouses; and, most importantly, what occurs at the Caves (Childs, 1999, p. 349).

The visit to Marabar caves brings out all the racial tensions and prejudices between the two communities. As Forster points out in the novel, 
The English always stick together! That was the criticism. Nor was it unjust. Fielding shared it himself, and knew that if some misunderstanding occurred, and an attack was made on the girl by his allies, he would be obliged to die in her defence. He didn't want to die in her defence. He didn't want to die for her; he wanted to be rejoicing with Aziz. (API, p. 235)

The visit is an unsuccessful attempt to show the two English ladies, Mrs. Moore and Adela Quested, real- not official- India. However, the emerged misunderstandings accompanied the expedition have tragic repercussions on both Aziz and the English women, owing to the immense cultural gaps between them. However, these racial and cultural gulfs bring about uncontrollable anger and detrimental repercussions on both Indians and the Anglo- Indians.

Race is one of the most challenging problems which impede any possible interracial relation between the Indians and the English expatriates. In a colonial context, Forster's APA explores the idea of what happens when two different races try to transgress the boundaries of race and come closer to each other. Thus, the novel excoriates the plague of racism and it explores its hideous ideologies. Transgressing race borders in India is forbidden; it is a strange action that may causes havoc and bring the wrath of the society on the transgressor whosoever. Fielding crosses his race boundaries and aspires to be a genuine friend of Aziz; however, this action fails when both Fielding and Aziz swerve part at the end of the novel. Therefore, both characters surrender to their racial differences, and they decide to put an end for their unhealthy friendship so long as India is under colonization.

Why can't we be friends now? Said the other, holding him affectionately. 'It's what I want. It's what you want.' But the horses didn't want it- they swerved apart; the earth didn't want it, sending up rocks through which riders must pass single-file; the temples, the tank, the jail, the palace, the birds, the carrion, the Guest House, that came into view as they issued from the gap and saw Mau beneath: they didn't want it, they said in their hundred voices, 'No, not yet, ' and the sky said, 'No, not there. (API, pp. 315-316)

By taking the side of Aziz, Fielding crosses his race boundaries and steps over this line. This infringement underscores a racial stereotype that an Englishman should never side with a local and he is advised to stick with his own race only. From the English expatriates' viewpoint, when Fielding steps out of his racial line, he not only loses his own self, but also puts his fellow Englishmen at risk. Following the trail scene and through the victory of Dr. Aziz, and by extension the victory of the entire Indian community, it transpires that the English colonizers are not always superior and the indigenous Indians are not inferior, which demolishes the colonizer's hierarchy beliefs.

In fact, East and West meet in harmony in the character of Professor Narayan Godbole, who seems to be a prophetic character. Godbole gives an answer to the racial conflict and the interracial intolerance suggested in the book. The carnival of Lord Krishna's birth in the last part of the novel, proposes regeneration and renewal. Among this racial uncertainty and hubbub, Professor Godbole's spiritual quest for salvation and peace is noteworthy. He embraces everything as deity and he goes beyond the chaos and nullity of his racial surroundings to reach out to the unity and affirmation which lie beyond the racial chaos. It is worth noting that Godbole's quest for the spiritual is beyond place and time as he endeavors to reach out the absolute through a full surrender of the self and extinction of his inner consciousness. Godbole's estimation of life comes close to the values of Forster; the redemptive power of Mrs. Moore is also partially derived from her spiritual association with Godbole. In light of this, the Hindu mystical views delineated in API by Godbole open the ideological closure of racism and reduce the interracial conflict in the book.

The writer presents the racial intolerance in turbulent colonial India meticulously. 'Race' divides people into distinct groups on the biological, ethnic and physical grounds. Human beings have always found ways of dividing themselves into small, large, superior, and inferior groups. In fact, human beings tend to divide themselves for wide-ranging considerations, such as language, religion, race, and so on. Therefore APA portrays an accurate and realistic picture of the nature of human world, also it demonstrates how efforts to split people on some grounds caused various cultural and social patterns that have gone deep into the psyche of human beings.

$A P I$ is a vibrant example of how two different races, cultures and ethnicities when forced to interact with each other, misunderstandings and miscalculations emerge. For example, Aziz and Mrs. Moore feel sensitive to each other and they interact passionately; nonetheless, it is their different racial boundaries and backgrounds which trammel this relationship, passion and harmony. Hence, it can be said that different racial backgrounds and racial intolerance can hinder any possible interracial understanding and openness of the ideological closure of racism. Thus, the book begins and ends by revealing the question of racial and cultural traumas and conflicts. Forster's novel thus frequently asks a very deep and controversial question, if it is possible for indigenous Indians to befriend the English colonizers, or vice versa.

$A P A$ is a tragedy of racial and interracial consternation. Adela Quested is occupied with a deep sense of anguish, shame and guilt; in fact, she has brought Aziz and the other Indian characters in the novel a great deal of suffering, pain, grief and loss. Melancholic and chagrined, the English woman is incapable of communicating here fears and anguish. As the trial begins, Adela withdraws her case against Aziz. Therefore, she develops a sense of humanity and suffers the guilt she has done to him selflessly. Universal and interracial respect, love, understanding and pure emotions are beyond race and color as they can bring people together regardless the different surroundings and racial settings. Accordingly, Miss Quested who begins her life journey from intellectuality to spirituality transgresses her racial boundaries and achieves salivation. The writer presents her as a daring woman rather than a disgrace to her white race. 
E.M. Forster clinically presents two different races, classes, and cultures, which are forced to interact in a colonial setting; nevertheless, doubt, suspicion, delusion, incitement, mutual accusations and misunderstanding surface as a result of this interaction. Forster once commented that in API he had tried to demonstrate the human predicament in an alien universe, which is not fathomable to our minds. In the novel, Forster purely expresses his annoyance and anger with some of the racist English foreigners he met during his stay in India. API is therefore a book of ulterior questions; it suggests that the two races cannot be true friends owing to their differences.

The novel exhibits a major fact about human nature; it shows some open-minded, liberal and genuine English individuals such as Mrs. Moore, Miss Adela Quested, Cyril Fielding, Ralph and Stella. On the other hand, it presents another group of shortsighted and intolerant Indian and Anglo-Indian characters. The book thus demonstrates that two different groups of people live in our world: the good and bad, the unbiased and biased, the racist and the liberal, the ugly and the beautiful, the open-minded and the shallow minded.

Dr. Aziz, an effusive widower and a well- learned Muslim doctor in Chandrapore city, however, he is neglected and mistreated by Major Callendar, an English doctor involved in racial prejudices and ethnic hatred against Aziz and the other Indian characters in the novel. Aziz is trapped as much as anybody else in the book. Aziz visits a nearby mosque to relieve himself from the frustration and anxieties caused by the English colonizers in general and by his senior English doctor in particular. On the other hand, Mrs. Moore is a devout Christian and she is well-liked and close to the natives. Mrs. Moore does not believe in racial fences, and for her all beings are equal irrespective of their cultural or ethnic backgrounds. However, these values cannot be possible in reality as human beings have the tendency to divide themselves based on either race, colour, gender, religion, language, etc. Thus, it can be argued that $A P A$ is pregnant with numerous racial scenes, discriminatory scenarios and interracial conflicts.

At the mosque, Aziz meets Mrs. Moore, an elderly English woman who wants to see and explore real India, not official India. This meeting establishes an emotional bond of sympathy and understanding between the two characters, "Madam, this is a mosque, you have no right here at all; you should have taken off your shoes; this is a holy place for Muslims" (API, p. 17). Both Aziz and Moore later become close friends and they reveal their hearts to each other; nevertheless, the racial and cultural differences swerve them apart. Dr. Aziz is glad that Mrs. Moore sympathizes with him being humiliated and embarrassed by the white man; however, his major delight stems from the fact that both feel for each other regardless their different racial surroundings.

Adela Quested, an inconvenient English woman, has also a profound yearning and quest to see real India, "I want to see the real India" (API, p. 21). In fact, she is eager to grasp, realize and feel real India culturally and socially through the perspective of her people and her race. Miss Quested identifies with Mrs. Moore; both believe that there should not be any significant racial fences, cultural, or religious gulfs between the two races: "There will have to be something universal in this country- I do not say religion, for I am not religious, but something, or how else are barriers to be broken down" (API, p. 23). The racial intolerance and cultural gulfs between the two communities are unequivocal; this is clearly seen in the words of Miss. Quested: "I have scarcely spoken to an Indian since landing" (API, p. 18). Hence, the English colonizers view the local Indians as inferior, unsophisticated and uncivilized on the ground of their race and colour.

The ominous events at the Caves possibly indicate Adela's infatuation with Dr. Aziz, which therefore highlight some racial stereotypes. Black race is believed to be sexually attractive to the white race, these stereotypes transpire clearly, when Adela intuitively compares Aziz's manliness to Rony and to her white race masculinity; she believes that Aziz would be attractive for his race. "She guessed he might attract women of his own race and rank" (API, p. 131). Accordingly, racial differences, stereotypes and miscalculations have turned to be a key aspect in the book.

In API, Cyril Fielding identifies with E.M. Forster himself. Compared with the other British expatriates in Chandrapore, Fielding is very humane, open- minded and liberal; arguably, he is the most successful character in the book being successful in establishing vigorous and healthy relationships with the locals. Different from other English colonials, Fielding does not discriminate between the expatriates and the locals on racial grounds, and he does not bear any bigotry or racial prejudices towards anyone. Unlike his race followers, Fielding does not avoid mingling with the natives, rather he endears himself to every Indian he meets. As a spokesperson for Forster, Fielding treats all Indian individuals with mutual prudence, esteem, love, generosity, and wisdom. As an individualist, Fielding therefore acts a as a successful bridge between the English colonizers and the indigenous Indians. Fielding's opinions about race matters are similar to Forster's attitudes. In his essay, "What I believe", Forster states that:

I believe in aristocracy, though -- if that is the right word, and if a democrat may use it. Not an aristocracy of power, based upon rank and influence, but an aristocracy of the sensitive, the considerate and the plucky. Its members are to be found in all nations and classes, and all through the ages, and there is a secret understanding between them when they meet. They represent the true human tradition, the one permanent victory of our queer race over cruelty and chaos. Thousands of them perish in obscurity, a few are great names. They are sensitive for others as well as themselves, they are considerate without being fussy, their pluck is not swankiness but power to endure, and they can take a joke. (1951, p. 5)

Both Aziz and Fielding share their emotions, opinions and feelings openly ignoring any racial prejudices. However, the racial un-commonalities and interracial traumas deform and curb their relationships. Cyril Fielding is a key figure in $A P I$. In the beginning of the novel, he crosses his racial boundary and rejects the racial absurdities to become a genuine 
friend with Dr. Aziz. In the end of the book, Fielding continues to be on the side of Dr. Aziz, a daring act totally unaccepted by the English community. Thus, API is a great literary masterpiece where Forster's dramatic development as a liberal author and humanist is observed; Forster transcends his traditionally middle-class aura to observe the sufferings of the marginalized and downtrodden community.

Although the central inquiry of the novel underlines the possibility of interracial friendship between the locals and the English expatriates, this task is strongly influenced by the intervention of two main forces: women and colonization. Forster's harsh and scornful satire on his English female characters is worthy of note; he portrays them as overwhelmingly racist, self-righteous, and viciously condescending to the locals (Pirnuta, 2007, p. 380). Fielding calls Miss Quested "priggish", as she appears to him a tragic creation of the Western Civilization. In the novel, Englishmen including Mr. Turton, Major Calendar, Ronny Heaslop, and Mr. McBryde are as cruel and racist as the English women; nevertheless, the writer more often identifies his English male characters as men who, though condescending and unable to relate to Indians individually, are well-meaning and invested in their jobs (Pirnuta, 2007, p. 380). Overall, the English expatriates, women or men, insult the Indians and treat them degradingly, the Indians nonetheless seem to expect and accept it.

Hence, it can be argued that English women in the book are a stronger representation of the British Empire than the English men in general, and their English husbands in particular. English women in the book assert bigotry, segregation, racialism, and they demand that their white husbands ignore Indians to spend some time with them. Mrs. Moore and Adela Quested are two exceptions in the novel; Mrs. Moore is too old to feel the sexual concern of younger women, and Quested embodies the curious spirit of a stranger in India. Both women outline the relationship between Dr. Aziz and Cyril Fielding; Mrs. Moore instigates it, Adela definitely puts an end for it. English women therefore represent the racial injustices of the British Empire, an empire with which Fielding ultimately allies himself by marrying an English woman (Mason, 2016, p. 53).

Aziz's endless sufferings at the hands of the British officials strengthen his national identity and promotes his belief that the English colonizers cannot rule over India anymore; seemingly, India itself affirms his national sentiments. The book's condemnation of friendship under colonization comes not only from Aziz, even nature itself rejects this untimely relations:

Why can't we be friends now?" said the other, holding him affectionately. "It's want I want. It's what you want." But the horses didn't want it - they swerved apart; the earth didn't want it, sending up rocks through which riders must pass single file; the temples, the tank, the jail, the palace, the birds, the carrion, the Guest House, that came into view as they issued from the gap and saw Mau beneath: they didn't want it, they said in their hundred voices, "Not, not yet," and the sky said, "No, not there." (API, p. 326)

Dr. Aziz puts a moratorium on his relationship and friendship with Cyril Fielding so long as his country is colonized; however, nature, landscapes, animals, the sky, and the cosmos condemn this friendship forever (Mason, 2016, p. 54). Sainsbury argues that, 'not there,' referring to that which escapes history's imprint, both contradicts 'not yet' and in the end overwhelms it," since the two statements are given equal weight" (2009, p. 61). Consequently, it can be argued that genuine friendships and healthy relations cannot be sustained within the arenas of colonialism and imperialism, no matter how accommodating the colonialists are. E.M. Forster ends his magnum opus literary masterpiece by asking the question of whether or not it is conceivable for Indians to befriend their English rulers in colonial India. E.M. Forster suggests that with mutual interracial love, goodwill, sagacity, and respect, all people of the world can connect themselves to each other irrespective of their backgrounds. API therefore describes ignoble and unhealthy interracial relations; it also highlights the despicable social conditions of a socially downtrodden and ostracized community. Forster reveals that racial intolerance and bigotry are cancerous; for Forster, class-distinctions and racial divisions are inappropriate and absurd.

\section{CONCLUSION}

E.M. Forster wrote API when India was in a state of severe cultural and racial turmoil; the country was going through turbulent political tensions and interracial conflicts. Forster is an individualist, a moralist and a humanist, and his views on interracial love, peace, tolerance, sympathy, mutual understating and harmony between races are openly highlighted in the novel. Nonetheless, these virtues and humanistic values are relatively unsuccessful in the Indian context. India is parted internally and externally owing to its religious, linguistic, and cultural diversities; therefore, it is subject to racial and cultural discrimination. Thus, cultural differences, interracial misunderstandings, racial intolerance, bigotry, traumas and discrimination are turned into a major theme in the novel.

The bitter conflict between the Indians the Anglo- Indians in colonial India does not seem to be only racial. In the novel, multiple motives obstruct any possible friendship between the colonized and the colonizer; there seems to be numerous barriers that prevent two extremes come closer to each other; such fences include the cultural, ethnic, religious, racial and linguistic differences. Aziz tells Fielding that the both the English people and the Indians cannot be true friends unless India is decolonized. Also Dr. Aziz tells Fielding that Indians bear the British for some political motives only, he states:

Clear out, clear out, I say. Why are we put to so much suffering? We used to blame you, now we blame ourselves, we grow wiser. Until England is in difficulties we keep silent, but in the next European war aha, aha! Then it is our time.... 
we may hate one another, but we hate you most. If I don't make you go, Ahmed will, Karim will, if it's fifty or five hundred years we shall get rid of you, yes, we shall drive every blasted Englishman into the sea. (API, pp. 315,316)

Foster closes API with the reconciliation act between both Dr. Aziz and Fielding. The novel carries a final message about interracial conflicts that although Aziz and Fielding seek genuine friendship, cultural, political, and historical conditions hinder such attachment. The final lines of the novel seem pessimistic, the writer however leaves the opportunity of a cross-cultural relations and friendship between the English and the Indians open. The author's message about interracial relations has developed throughout the book. At the opening of the novel, characters such as Fielding and Aziz are evidence of Forster's belief that individuals can connect with intelligence, good will and respect. Nevertheless, in the final scenes of the book, even the Indian natural landscape seems to reject this untimely friendship, and thus separate them from one another. This suggests that though people may be well-intentioned, external circumstances such as ethnic difference and racial and cultural conflicts conspire to prevent any potential union.

Different cultural variations and expectations regarding social properties and the role of religion in people's lives are also responsible for widening the gap between the two communities. These variations are also responsible for many misunderstandings take place between the Indians and the English rulers, the English and the Hindu Indians, and between the Muslims and the Hindus. The novel suggests that interracial relations between the two different ethnicities, the white imperialists and the Orientals, cannot work efficiently in a colonial context. In light of $A P A$, the Occident feel that they are quite superior to the Eastern, the other; therefore the white supremacists have tried to inculcate feelings of inferiority and subjugations into the minds of the colonized. In view of this, APA describes the despicable and ignoble conditions of the Indians being marginalized and socially downtrodden by the English colonizers. Forster points out that ultimately the racial intolerance and the problem of race which divide human experience have detrimental outcomes on the colonizers and colonized alike; the writer also points out the inapplicability and absurdity of class distinctions and racial conflicts. The novel suggests that the Hindu mysticism and mystical views, best exemplified in the novel by Godbole, the Hindu philosopher, can open the ideological closure of racism and thus alleviate interracial conflicts. It is concluded that Interracial and mutual love, respect, tolerance and understanding can in a colonial context overcome all differences and tensions irrespective of the cultural, religious, linguistic and racial variations, but this is an excuse for the weak to justify the dominance of the other.

\section{REFERENCES}

[1] Ashcroft, B., et al. Eds. (1995). The post-colonial studies reader. London: Routledge.

[2] Bhabha, H. K. (1994). The Location of Culture. London \& New York: Routledge.

[3] Brandabur, Clare. (1993). 'Images of women in five post-colonial novels', Aegean Journal of Language and Literature, proceedings of 13th All-Turkey English Literature Conference 1992 (special issue), Izmir.

[4] Childs, P. (1999). Post-Colonial Theory and English Literature; A Reader. Edinburgh: Edinburgh UP.

[5] Devi, R. (2017). 'Cultural Conflicts and Disordered Relationship in E. M. Forster's A Passage to India'. IJRAR-International Journal of Research and Analytical Reviews, 4(2): 223-226.

[6] Ford, B. (1983). The New Pelican Guide to English Literature. London: Pelican.

[7] Forster, E.M. (1951). What I Believe. Two Cheers for Democracy (p.p.5-22).New York: Harcourt, Brace.

[8] Forster, E. M. (1979). A Passage to India. London: Penguin Books Ltd.

[9] Lan, W. (2013). 'The dislocation of identity and an elegy for empire: E.M. Forster and his A Passage to India'. Forum for World Literature Studies, 5(3):492-502.

[10] Mason, S. A. (2016). Images of the Other: Race, Gender, and the Imperial Relationship in The Heart of Darkness, a Passage to India, and Burmese Days. (English Undergraduate Honors Theses). University of Arkansas, Fayetteville. Retrieved May 3, 2021, from https://scholarworks.uark.edu/engluht/7

[11] Pirnuta, O. (2007). Indian Vs British Cultural Aspects in E.M. Forester's A Passage to India. Editura University.

[12] Priestley, J. (1962). B. Literature and the Western Man. London: Heinemann.

[13] Sainsbury, A. (2009). 'Not yet... not there': breaking the bonds of marriage in EM Forster's A Passage to India. Critical Survey, 21(1), 59-73.

Rashed Daghamin holds a PhD in English Literature from the University of Allahabad, India. He currently serves as an Assistant Professor of English, University of Hail, Saudi Arabia; he formerly served the same post at Hebron University and Al-Quds University, Palestine. Daghamin teaches a wide spectrum of literature courses mainly courses on $19^{\text {th }}$ century poetry and fiction, modern drama, and modern poetry. His research interests lie primarily in the area of poetry, Contemporary Literary Theory, Palestinian literature, Black Literature, Creative Writing, Postcolonial Literature, and African American Studies. ORCID ID: https://orcid.org/ 0000-0001-7331-6012 